\title{
Input, Output, and Behavioral Additionality of Innovation Subsidies ${ }^{\star *}$
}

\author{
Edgard Alberto Méndez-Morales ${ }^{1 *}$, Daniela Muñoz ${ }^{1}$
}

\begin{abstract}
Using a Conditional Difference in Difference procedure and data for Colombia, we determine if firms that receive subsidies to innovation in the period 2010-2016 present additionality on input, output, and behavioral innovation variables. We found that there are differences among the additionalities of small and medium firms (SMEs) and big firms, and the existence of a crowding-out effect for internal R\&D expenditures in SMEs. At the same time, we found additionality on R\&D employment for all types of firms and the presence of experience effects introduced by subsidies, especially for SMEs. These effects are related to positive additionalities. At the same time, we cannot find additionality effects on patents and trademarks. However, we found negative additionality on sales of big companies that we relate with the way we measure this variable.
\end{abstract}

Keywords: Parametric matching, R\&D\&i, difference in differences, DANE, abandonment, patents, trademarks, innovation impediments

Submitted: January $10^{\text {th }}, 2019 /$ Approved: November $8^{\text {th }}, 2019$

\section{Introduction}

Innovation economics has been focused on business innovation as an economic growth driver. According to literature, the way innovation and regional and national economic growth are connected is through the firms productivity increase (Färe, Grosskopf, Fukuyama, \& Margaritis, 2011; Nelson, 1959), and therefore, one may think that regions and countries all around the world seek to maximize their R\&D\&i (Research, Development and Innovation) investments as a way to improve their productivity. However, it is possible to find in those countries substantial differences in the investment levels, especially in underdeveloped countries whose investments in R\&D\&i are less than low.

Some of the causes found in literature as an explanation of those differences between developed and underdeveloped economies are related to the existence of market failures. In the case of R\&D\&i ventures, it seems to be more frequent and stronger than other types of ventures, like fixed capital investments (Hall \& Lerner, 2009). In the first place, firms cannot privately appropriate all the benefits of their investments, given that knowledge generated inside the firm becomes a public good; that is, knowledge is a non-rival and non-exclusive asset. Therefore, even when there is a social expectation for more R\&D\&i private investment, firms face a disincentive to finance a public good privately.

Secondly, information asymmetries in the case of R\&D\&i projects are strong; this market failure causes future expectations about the results of innovation projects to be uncertain, both for the company and for its potential external funders (Hall \& Lerner, 2009). The latter means that $\mathrm{R} \& \mathrm{D}$ ventures are risky, and therefore, external financial costs are higher for these type of projects, then, companies investment level is lower than the socially desired one, since the private and social returns of this type of investments diverge (Arrow, 1972).
The fact that knowledge generated by firms on R\&D\&i projects becomes a public good is related to what is known in the literature as spillover effects. These effects, generally positive, can benefit firms that carry out R\&D\&i expenditures, their rivals, and in general, the market in which these companies are located (Jaffe, Trajtenberg, \& Henderson, 1993). In such a way, society wants private companies to invest in R\&D\&i projects to generate such spillover effects. However, as already anticipated, private firms will not be willing to finance the entirety of these investments. In this sense, public investment in R\&D\&i plays a preponderant role, since it is called to replace the lack of private investment funds as a way to generate the spillover effects sought by society (G. Crespi, Garone, Maffioli, \& Melendez, 2015).

In order to encourage firms to invest in R\&D\&i, governments promote some policies focused on increasing the quantity and quality of projects; two of these incentives are tax deductions and business subsidies for carrying out R\&D\&i ventures. However, given that governments must prioritize their expenditures towards programs where more significant impacts are expected, the evaluation of the effects caused by such aids is fundamental, especially in underdeveloped countries, where budget deficits are substantial.

However, assessing the effect that public R\&D\&i policies have on private companies and the society is not an easy task, especially for policymakers, which most of the time have data restrictions related to the intangibility of the results of this type of ventures (David, Hall, \& Toole, 2000). That is, in some cases, policymakers cannot even make measurements that allow them to understand if subsidies given to the private sector have generated some effect on firms and society.

In the last 30 years, innovation researchers have tried to measure spillover effects generated by public policies, especially in the case of business subsidies for carrying out R\&D\&i ventures. These effects are named additionality effects, and are generally grouped in three

1) Economic sciences department, Universidad Militar Nueva Granada, Bogotá, Colombia.

*Corresponding author: edgard.mendez@unimilitar.edu.co

** Financed by Universidad Militar Nueva Granada under the project INV-ECO-2583 "Impacto de los subsidios de innovación en las empresas colombianas. Un análisis desde la encuesta de innovación del DANE. 
different types of effects. First, input additionality, e.g. increase in private $R \& D$ expenditure, employment increase, etc.; secondly, output additionality, e.g. increase of innovative products and services revenues, propensity to register patents, etc.; and third, behavioral additionality e.g. propensity to innovate, effects on the number of abandoned or delayed innovation projects, etc. However, literature about subsidy effects has been largely focused on determining the effects of input additionality, but the other types of additionalities have been left aside, especially those related to the firm's behavior.

It is essential to point out that when it comes to assess the effects of innovation subsidies, the temporality of the study is not a trivial matter, because additionality can occur in the short term, as it is the case of input additionality; e.g., a firm spends more on R\&D as soon as it receives a public subsidy for innovation. However, it can also occur in the long term, as it is the case of output additionality; e.g., the company will achieve sales of innovative products once they carry out an innovation project and manage to convince the market of the advantages of their products and services. However, the last happens in the middle and long term, so it is essential to focus not only on the short but also in the long term (Zúñiga-Vicente, Alonso-Borrego, Forcadell, \& Galán, 2014).

On the other hand, even though in the last 30 years, a genuine interest has been generated in the evaluation of R\&D\&i policies through subsidies, the vast majority of these evaluations are carried out in developed countries. In the case of Latin American and developing countries, there is not a large number of studies, due in part to the fact that not all countries have the microdata needed to carry them out (innovation surveys based on the Oslo Manual). Similarly, in the vast majority of literature, studies focus on input additionality, specifically in R\&D expenditure, trying to determine if there is a crowdingout effect between public subsidies and private spending on R\&D\&i (Zúñiga-Vicente et al., 2014) but letting behavioral and output additionality aside.

Within Latin American countries, Colombia stands out for its lack of investment in R\&D\&i; its total expenditure for 2017 raises to $0.24 \%$ of GDP, of which only $49 \%$ was financed with private resources. This shows there is a problem regarding the interest of private firms in carrying out this type of projects; however, it also shows that public resources, which finance $48 \%$ of the total investment (OCyT, 2017), should be prioritized for those projects having the most significant impacts, given that there are few resources to invest.

This study is carried out through a data panel of Colombian manufacturing companies between 2009 and 2016 generated through the Survey of Development and Technological Innovation (Encuesta de desarrollo tecnológico e innovación tecnológica-EDIT). This research aims to estimate the impact of innovation subsidies on input, output and behavioral additionality of Colombian companies in the long term.

The article is structured as follows: A brief literature review related to the evaluation of the innovation subsidies and methodologies that have been applied by researchers to solve some methodological issues. Afterwards, the methodology, data set, and variables used will be explained. In the fifth section, the results of an econometric strategy are presented, and in the final section will be the conclusions, discussion, and limitations of the study.

\section{Literature review}

In recent years, the literature on the effect that subsidies to innovation have on firms has grown exponentially. Generally, this literature has used innovation surveys based on the Oslo Manual (OECD, 2005) and has had to deal mainly with a problem of endogeneity, that is, subsidies are not given randomly, and therefore, they are determined by the same variables for which it is required to measure its rate of change before and after the subsidy (e.g. R\&D expenditure). In such a way, multiple methodologies have been used to overcome this problem, e.g. the Heckman selection models, instrumental variables (IV), parametric matching, difference in differences (DID), and doseresponse models. Each of them has different approaches, but they have as a common factor that they try to overcome the problem of endogeneity, and in some cases, as with the DID methodology, heterogeneity for not observable firm variables can also be controlled [for a thorough review of these methodologies see Cerulli (2010)].

The literature on the effect of subsidies on innovative firms began in the 2000s, seeking to determine if there was a crowding-out effect on the companies internal $\mathrm{R} \& \mathrm{D}$ expenditure. In general, these studies found this effect is positive, and firms receiving subsidies end up spending a higher amounts of R\&D than they would have spent without the subsidy, that is, the so-called input additionality effect (Aerts \& Czarnitzki, 2004; Aerts \& Schmidt, 2008; Almus \& Czarnitzki, 2003; Busom, 2000; Cerulli \& Potì, 2008, 2016; Choi \& Lee, 2017; Chudnovsky, Lopez, Rossi, \& Ubfal, 2006; Cin, Kim, \& Vonortas, 2017; Czarnitzki \& Delanote, 2015; Czarnitzki, Ebersberger, \& Fier, 2007; Czarnitzki \& Hussinger, 2018; Czarnitzki \& Lopes-Bento, 2012, 2013, 2014; Engel, Rothgang, \& Eckl, 2016; González \& Pazó, 2008; Görg \& Strobl, 2007; Heshmati \& Lööf, 2005; Jiang et al., 2018; Lach, 2002; Sanguinetti, 2005).

At the same time, it can be expected that the effects of innovation subsidies tend not to be exclusive for input additionality, but also on other types of variables such as behavioral ones. The idea behind the behavioral additionality is that a company, after receiving a subsidy, changes its behavior, it is managed under a new logic, and performs its innovation processes differently. Therefore, it is possible to measure such changes before and after the subsidy. Authors such as Autio, Kanninen \& Gustafsson (2008) have shown that the forms of learning-related with technology, market, and internationalization increase positively after receiving a subsidy. Similarly, Clarysse, Wright, and Mustar (Clarysse, Wright, \& Mustar, 2009) find that government subsidies have a substantial impact on the formalization of innovation processes, in the generation of capabilities to manage innovation, and in the research trajectories of business. In the same path, Wanzenböck, Scherngell, and Fischer (2013) show that once companies receive subsidies to innovation, the likelihood of abandoning their innovation projects decreases, the cooperative behavior increases, and 
the knowledge transfer flows become more visible. At the same time, Tello (2015), Busom and Vélez-Ospina (2017), and Jiang et al. (2018) show that companies receiving subsidies tend to increase their propensity to innovate. However, the literature on the effects of subsidies on behavioral additionality is not widely disseminated, and generally, literature about innovation subsidy focuses on the input additionalities of innovation (Dimos \& Pugh, 2016).

Simultaneously, the effects generated by subsidies could also be measured on innovative output results; that is, subsidies can also generate output additionalities. Some researchers have shown that these effects are highly visible, and therefore, they can be taken into account as a way to evaluate R\&D\&i government policies. In this direction, Czarnitzki and Lopes-Bento (2014) show that companies receiving subsidies have a higher propensity to register patents; these results are in line with those by Czarnitzki, Ebersberger and Fier (2007), Czarnitzki and Delanote (2015), Widmann (2016) and Czarnitzki and Hussinger (2018). Likewise, the articles by Crespi and Maffioli (2014), Crespi et al. (G. Crespi et al., 2015), and Cin, Kim, and Vonortas (2017) show that firms in Latin America and Korea tend to improve their labor productivity after receiving an innovation subsidy. In the case of Austria, García and Mohnen (2010) indicate that the proportion of innovative sales increases by $3,4 \%$ for firms obtaining an innovation subsidy. This is a significant additionality effect, given that it is assumed that one of the main objectives of subsidies is to reduce the uncertainty of innovation projects and generate profitability for the companies receiving them. In the end, this profitability must come from a higher flow of revenues. However, Karhunen and Huovari (Karhunen \& Huovari, 2015) show with data from Finland that labor productivity in SMEs seems not to be affected after a subsidy reception, even when this type of policies tends to increase the firms' human capital levels; also, Catozzella and Vivarelli (2011) show with data from Italy that innovation productivity tends to be reduced after subsidy; this could be a result of the innovation cost increase, but also because of the decrease of innovation revenues.

Researches like Aboal and Garda (2015), Crespi et al. (G. Crespi et al., 2015), Bodas-Freitas et al.(2017), Guo, Guo and Jiang (2016), and Howell (2017) show that firms receiving subsidies tend to increase their sales of innovative products, not in the short term, but the long term. The last point is essential to determine the actual additionality effects of innovation subsidies. Innovation projects usually deliver results in the long term; however, a large part of research on this topic focuses on short-term additionality effects, especially those that used propensity score matching methodologies (Zúñiga-Vicente et al., 2014). In recent years, literature has begun to show the long-term effect of subsidies by finding there are greater effects in the long term than those estimated in the short term (Bodas-Freitas et al., 2017; Cin et al., 2017; G. Crespi et al., 2015; Engel et al., 2016; Guo et al., 2016; Howell, 2017; Karhunen \& Huovari, 2015; Tello, 2015; Widmann, 2016).

Similarly, as evidenced by Zúñiga-Vicente et al. (2014), studies on the additionality of subsidies are mainly focused on developed countries and have not paid much attention to these effects on developing countries. As we understand it, this fact has a fundamental justification, the lack of micro-data in which to look for evidence of additionalities in developing countries. Since the first decade of the 2000s, the exercises carried out in Europe through the Community Innovation Surveys (CIS) based on the Oslo Manual (OECD \& Eurostat, 1997) have allowed the detailed study of this and other phenomena related to innovation. However, in the case of developing countries, the lack of micro-data has not allowed additionalities to be studied sequentially. However, it is possible to find some valuable examples for developing countries, especially in the case of Latin America as it can be seen in Sanguinetti (2005), Chudnovsky et al.(2006), and Crespi et al.(2016) for Argentina; Fernández-Sastre and Martín-Mayoral (2015) in the case of Ecuador; Tello (2015) for Peru; Aboal and Garda (2015) in Uruguay; Crespi et al.(G. Crespi et al., 2015), Busom and Vélez-Ospina (2017), and Barrios, Forero and Perry (2018) for the case of Colombia, and the literature review of Crespi and Maffioli (2014) for all Latin America.Methodology

It is possible to see that literature about innovation subsidies additionalities has been overlooked; first, the effects of subsidies on other variables different from the ones measuring input additionalities. Second, the long-term effects of subsidies on firms. Third, the impact of innovation subsidies on firms of underdeveloped countries. In such a way, this research is a small effort to understand the long-term input, output, and behavioral additionality for manufacturing firms in an underdeveloped country like Colombia.

\section{Methodology}

The method used in this research is "Conditional Difference in Differences" (CDID). This method consists in combining a parametric matching methodology with a difference in difference model, where the average differences of the control and treatment group before the subsidy are compared against the same differences after the subsidy granted in the follow-up period.

For our data, we do not have a randomized experiment since subsidies are not given randomly. Therefore, it is not possible to compare directly firms receiving subsidies against companies that do not receive them, because their initial and final conditions are differentiated by other factors different from subsidies. That is the reason why the first step of the CDID methodology is to use a matching method. With this technique, it is possible to identify a subsided company and their counterpart, i.e., another firm that does not receive subsidies, but with the same likelihood of receiving government aid, and therefore, with similar characteristics compared with a subsided firm before receiving grants. This is done through a set of observable firm characteristics. This pairing method, called propensity score matching (PSM), allows us to return to the conditions of a randomized experiment (Chudnovsky et al., 2006) in which the results of input, output, and behavioral variables are compared in the base year (2010). The PSM consists of determining the average treatment effect on the treated (ATET): 


$$
\operatorname{ATET}=\mathrm{E}\left(\mathrm{Y}_{\mathrm{i} 1} \mid \mathrm{D}_{\mathrm{i}}=1\right)-\mathrm{E}\left(\mathrm{Y}_{\mathrm{i} 0} \mid \mathrm{D}_{\mathrm{i}}=1\right)
$$

Where $\mathrm{Di}$ is a dichotomous variable with the value one (1) if the firm received subsidies, and zero (0) otherwise. $Y_{i 1}$ is the response variable being measured for firms with a subsidy, i.e., in the treatment group, and Yi0 is the response variable being measured for firms without subsidy, i.e., in the control group. In the case of innovation subsidies, response variables could be grouped on input, output and behavioral variables.

The term $E\left(Y_{\mathrm{i} 1} \mid D_{\mathrm{i}}=1\right)$ indicates the average effect of the response variable $\mathrm{Y}_{\mathrm{i}}$ for a company in the treatment group and receiving subsidies, and $E\left(Y_{\mathrm{i} 0} \mid D_{\mathrm{i}}=1\right)$ reflects the average effect of the response variable for a company in the control group and receiving subsidies. However, the last term is not observable and is counterfactual, since the effect of the subsidy cannot be seen in a company that did not receive it; therefore, this value must be estimated.

Assuming a CIA (Conditional Independence Assumption) between subsidies and the response variable, a set of observable characteristics $\mathrm{Xi}$, used to select granted firms could be applied to determine the outcomes of non-treated (control) firms. Therefore, it can be said that:

$$
E\left(Y_{\mathrm{i} 0} \mid X_{\mathrm{i}}, D_{\mathrm{i}}=1\right)=E\left(Y_{\mathrm{i} 0} \mid X_{\mathrm{i}}, D_{\mathrm{i}}=0\right)
$$

That is, it can be assumed that taking into account the set $\mathrm{X}_{\mathrm{i}}$ of variables, the expected value of $Y_{i}$ for companies belonging to the control group and receiving subsidies (counterfactual) must be identical to the non-observable value of variables in control group not receiving subsidies. Rosenbaum and Rubin (1983) addressed this issue, demonstrating that, if CIA is valid, this problem is facilitated by reducing the set of variables $\mathrm{Xi}$ in a single index, called propensity score, as long as it is consistently estimated by a parametric model, in this case, a probit model:

$$
\operatorname{Pr}\left(D_{\mathrm{i}}=1 \mid X_{\mathrm{i}}\right)=F\left(X_{\mathrm{i}}\right)=\int_{-\infty}^{X_{i}} \frac{1}{\sqrt{2 \pi}} \exp \left(-\frac{1}{2}\left(X_{i}\right)^{2}\right) d x
$$

The probit model result is the estimated likelihood of a firm to be granted by government subsidies, and it is used to match treated and control firms. Keeping this in mind, the calculation of ATET will be:

$$
A T E T=E\left(Y_{\mathrm{i} 1} \mid X_{\mathrm{i}}, D_{\mathrm{i}}=1\right)-E\left(Y_{\mathrm{i} 0} \mid \mathrm{X}_{\mathrm{i}}, D_{\mathrm{i}}=0\right)
$$

However, given that we want to determine the long-term effect of subsidies using panel data, the way to implement this methodology is through a DID procedure:

$$
\left.A T E T_{\mathrm{t}}=E\left(Y_{\mathrm{iltt}} \mid X_{\mathrm{it}-1}, D_{\mathrm{it}}=1, D_{\mathrm{it}-1}=0\right)-E\left(Y_{\mathrm{iot}} \mid X_{\mathrm{it}-1}, D_{\mathrm{it}}=0, D_{\mathrm{it}-1}=0\right)\right)
$$

The explained methodology allows us to control by observed heterogeneity and counterfactuality through the matching procedure; at the same time, the use of a DID procedure allows us to control by nonobservable invariant firm characteristics (Aerts \& Schmidt, 2008). The CDID procedure was developed with the methodology proposed by Villa (2016)I present the features of the user-written command diff, which estimates difference-in-differences (DID.

\subsection{Data}

The data set used for this study was developed by the National Administrative Department of Statistics (DANE, for its acronym in Spanish) in the Survey of Development and Technological Innovation (Encuesta de desarrollo tecnológico e innovación tecnológica [EDIT]). EDIT is a biennial survey, and we use EDIT V (2009 2010), EDIT VI (2011 - 2012), EDIT VII (2013 - 2014), and EDIT VIII (2015-2016). The survey follows the methodology of the Oslo Manual (OECD, 2005) and Bogotás Manual (Jaramillo, Lugones, \& Salazar, 2000) to collect firm-level characteristics like the amount of $\mathrm{R} \& \mathrm{D}$ expenditures, cooperation activities, R\&D labor, among others. This survey was developed for manufacturing firms, and it is statistically representative at a national level.

The variables used are divided into four groups. The first one is the group used to generate our propensity score using a probit model. The second group of variables is the one measuring input additionalities of firms. The third group measures behavioral additionalities. The last one measures output additionalities. Description of variables can be seen in Appendix A.

We use the 2010 survey as our base treatment moment and 2016 as the follow-up year. The objective behind this was to measure longterm additionalities of firms receiving subsidies. We use firms with more than ten employees and not receiving subsidies in the period 2008-2009. At the same time, we divided our firms into SMEs and big firms to confirm if the additionalities affect in different ways those types of firms; A summary of our data used can be seen in Appendix B.

\section{Results}

To perform our matching methodology, we use a probit model in which variables related to subsidies granting are included (see Appendix A). This regression was performed for firms of the 2010 survey. Results of this model are posted in Table 1.

Table 1 Probit model regression

Probit model for companies with more than ten employees. Survey 2010. Firms are not receiving subsidies in 2008-2009.

\begin{tabular}{llll}
\hline & Coef. & $\mathrm{P}>|\mathrm{Z}|$ & Std. error \\
\hline lnsize & 0,274 & $0,001^{* * *}$ & 0,085 \\
medium_tech & 0,332 & 0,237 & 0,281 \\
medhigh_tech & 0,566 & $0,026^{* *}$ & 0,255 \\
high_tech & 0,570 & 0,157 & 0,403 \\
and_reg & 5,101 & $0,000^{* * *}$ & 0,520 \\
bog_reg & 5,127 & $0,000^{* * *}$ & 0,525 \\
_cons & $-8,627$ & \\
\hline & $\begin{array}{r}\text { Number of observations: } 736 \\
\text { Prob }>\text { chi2 }=0,000\end{array}$ \\
& $\begin{array}{r}* * \text { p }<0.01 ;{ }^{* *} \mathrm{p}<0.05 ;{ }^{*} \mathrm{p}<0.1 \\
\text { Source: Our own calculations. }\end{array}$
\end{tabular}


Variables like firm size, belonging to medium-high technology industries, and firm location in principal geographic areas like Bogotá and Andean Region seem to be related to subsidies in Colombia. After this procedure, we perform several t-tests on the equality of means of Appendix A variables related to input, output, and behavioral additionalities. The result of these tests can be seen in Table 2. Before the matching procedure, control firms tend to have a higher number of employees and belong in more significant proportions to high and medium technology sectors. However, after the matching procedure, differences disappear, and therefore, we are ready to perform a difference in difference procedure given that control and treated firms seem to have no differences. In appendix C. we have included a common support analysis in order to understand if, after matching, the balancing property is satisfied. As the reader may appreciate, after the fourth block, we reach the balancing property using 736 firms; therefore, we can now the average treated effect on the treated using the difference in difference procedure.
Table 2. T-test on equality of means. Treated Vs. control firms in 2010 survey

T-Test for treated and control firms before and after the balance All firms with more than ten employees. Survey 2009-2010. Firms' nonreceiving subsidy in the period 2007-2008.

\begin{tabular}{lcccc}
\hline & $\begin{array}{c}\text { Differences before } \\
\text { matching } \\
\text { [Treated-Control] }\end{array}$ & Prob. & $\begin{array}{c}\text { Differences after } \\
\text { matching } \\
\text { [Treated-Control] }\end{array}$ & Prob. \\
\hline Insize & $-0,886$ & $0,004^{* * *}$ & $-0,053$ & 0,603 \\
medium_tech & $-0,003$ & 0,974 & $-0,044$ & 0,137 \\
medhigh_tech & $-0,187$ & $0,055^{*}$ & $-0,058$ & 0,103 \\
high_tech & $-0,031$ & 0,646 & $-0,005$ & 0,827 \\
and_reg & $-0,113$ & 0,327 & 0,051 & 0,165 \\
bog_reg & $-0,110$ & 0,339 & 0,058 & 0,111 \\
\hline
\end{tabular}

${ }^{* * *} \mathrm{p}<0.01 ;{ }^{* *} \mathrm{p}<0.05 ;{ }^{*} \mathrm{p}<0.1$

Treated firms 21. Control firms 715. Total firms 736

Source: Own calculations

We calculate ATET with 2010 as our base period and 2016 as our follow-up period. Results of this procedure can be seen in Table 3.

Table 3. Average Treatment Effect on the Treated (ATET). All firms included.

\begin{tabular}{|c|c|c|c|c|c|}
\hline Type of additionality & Variable & $\begin{array}{l}\text { base period diff } \\
\text { (treated-control) }\end{array}$ & $\begin{array}{c}\text { follow-up period diff( } \\
\text { treated - control) }\end{array}$ & $\begin{array}{c}\text { diff in diff } \\
\text { (Follow up - Base period) }\end{array}$ & $P>|t|$ \\
\hline \multirow{4}{*}{ input } & rdint & $-0,746$ & 0,445 & 1,191 & $0,000^{* * *}$ \\
\hline & rdext & 0,289 & 0,004 & $-0,285$ & $0,001^{* * *}$ \\
\hline & expinn & $-0,457$ & 0,449 & 0,906 & $0,012^{* * *}$ \\
\hline & rd_size & $-10,667$ & 16,691 & 9,896 & $0,006^{* * *}$ \\
\hline \multirow{6}{*}{ behavioral } & ongoing & 0,012 & $-0,055$ & $-0,068$ & 0,249 \\
\hline & imp_fin_internal & $-0,005$ & 0,080 & 0,085 & 0,150 \\
\hline & imp_innprofit & $-0,085$ & $-0,153$ & $-0,068$ & 0,249 \\
\hline & imp_fin_ext & 0,174 & 0,206 & 0,031 & 0,585 \\
\hline & coop_total & 0,217 & 0,221 & 0,005 & 0,929 \\
\hline & coop_amplitude & 1,263 & 0,653 & $-0,610$ & $0,016^{\star *}$ \\
\hline \multirow{3}{*}{ output } & dummypatents & $-0,086$ & $-0,050$ & 0,036 & 0,125 \\
\hline & tmarks_ip & $-0,047$ & $-0,026$ & 0,021 & 0,718 \\
\hline & nfnatsales & 0,220 & 0,086 & -0.135 & $0,021^{* *}$ \\
\hline
\end{tabular}

${ }^{* * *} \mathrm{p}<0.01 ;{ }^{* *} \mathrm{p}<0.05 ;{ }^{*} \mathrm{p}<0.1$

Number of observations in the base period 736 ( 21 treated, 715 controls); the number of observations in follow up period 522 ( 39 treated, 483 controls). Source: Own calculations.

It can be seen that when we included all firms in our analysis, input additionalities tend to be strong. Differences in internal R\&D expenditures move from being negative in favor of non-subsided control firms to being positive in favor of treated firms for almost 1.2 million COP. Therefore, we can discard a crowding-out effect related to internal R\&D. However, external expenditures on R\&D move in the other direction. In 2010, treated firms expended more than control firms did, but in 2016, this situation reversed. It seems that subsided firms tend to diminish their external expenditure. Apparently, in the long term, firms tend to privilege the internal formation of capabilities and diminish external knowledge acquisition. This is, in the long term, com- panies tend to generate its knowledge in house, instead of buying it. The sum of total R\&D and innovation seems to increase as a result of a higher effect of internal R\&D in almost 0,9 million COP. Employees related to $R \& D$ in 2010 were higher for control firms; however, after subsidies, treated firms tended to have almost ten more employees than non-subsidized control firms. This is important given that we assume these types of employees have high qualifications. Therefore, innovation subsidies create high-value employment.

Results for behavioral additionalities are no good. Treated firms do not elevate the number of ongoing projects and do not improve their per- 
ception of innovation barriers. However, treated firms diminish their cooperation amplitude; that is, these firms tend to collaborate with fewer types of institutions. We interpreted these results as a cooperation specialization, i.e., firms tend to privilege relationships with fewer types of institutions but might be increasing the strength of those relationships.

Output results show that patents and trademarks have no effects when the full sample is used. Innovation revenues, on the other side, seem to have negative additionalities, that is, differences of control and treated firms tend to decrease in the long run in favor of control firms. Given that we are using only revenues for new to the firm products and services as a way to measure innovation output, we believe this result could be an outcome of a dichotomy between new to the market revenues and new to the firm revenues. Our sales variable was constructed using a percentage of total new to the firm innovative revenues, and then we re-expressed this number into a dummy variable. It is possible that the percentage of new to the market revenues increases while the complement percentage of new to the firm revenues decreases. Maybe, the negative sign of our sales variable could be the result of non-observed additionality on new to the market innovative revenues. However, we cannot confirm this as we do not have enough observations for new to the market revenues. Another plausible explanation of the negative sign could be the low efficiency of externally funded innovation expenditures against private funding expenditure as it was founded by Catozzella and Vivarelli (2011).

\subsection{Results on small and medium enterprises}

When the procedure is developed for SMEs, the results are quite interesting and can be seen in Table 4 . In the first place, SMEs present a significant crowding-out effect for internal $R \& D$ expenditure. That is, SMEs tend to expend less money on internal R\&D after subsidies. This result is contrary to the one obtained when we used the full sample; this is interesting since we can say not all firms tend to act in the same way after subsidies. At the same time, SMEs tend to expend more money on external R\&D acquisition; therefore, we can say these firms tend to privilege external over internal knowledge after subsidies. When we measure the effect over total R\&D, the decreasing effect of external knowledge acquisition is higher than the one of internal $R \& D$. Therefore, there is a crowding-out effect on total $R \& D$ expenditure. Simultaneously, R\&D employment tends to increase for subsided SMEs; on average, in the long term, subsided SMEs augmented R\&D employees more than the control SMEs in 4,3 employees.

Regarding behavioral additionalities, results are interesting, too. Ongoing innovation projects tend to increase for SMEs after subsidy; that is, firms with an active project in the survey period are $21 \%$ higher for subsided against control companies. Impediments regarding internal and external funding tend to increase for treated firms also; this seems to be a negative result given that firms tend to perceive more financial barriers after than before subsidy. However, we have a plausible explanation for this result; in several researches like the ones of Baldwin and Lin (2002), D'Este, Iammarino, Savona and Von Tunzelmann (2012) or Pellegrino and Savona (2017), it has been found that some financial impediments tend to increase after a firm generates some experience on innovation ventures. The reason behind this is there are some firms without innovation projects, which tend to respond "no" to the question: Does your firm perceive a financial impediment to perform innovative projects in the last year? because they have no experience in day-by-day innovation projects. However, firms tend to have a higher perception of impediments after they involve on more $R \& D$ ventures because they begin to understand the way innovation is made. Overall, we consider this result can be a signal of firms gathering experience on innovation projects; therefore, we hypothesize it is an experience effect that could not be possible if these firms did not receive subsidies. At the same time, the perception that innovation has not been profitable tends to decrease, and we believe this is also an experience effect created by the possibility to involve in $R \& D$ ventures after receiving subsidies. On the other side, we do not find any changes in cooperation variables or innovation output variables.

Table 4. Average Treatment Effect on the Treated (ATET). SME's.

Difference in differences procedure for SME's. Firms with more than ten and less than 200 employees. Base period=2010; Follow up period=2016

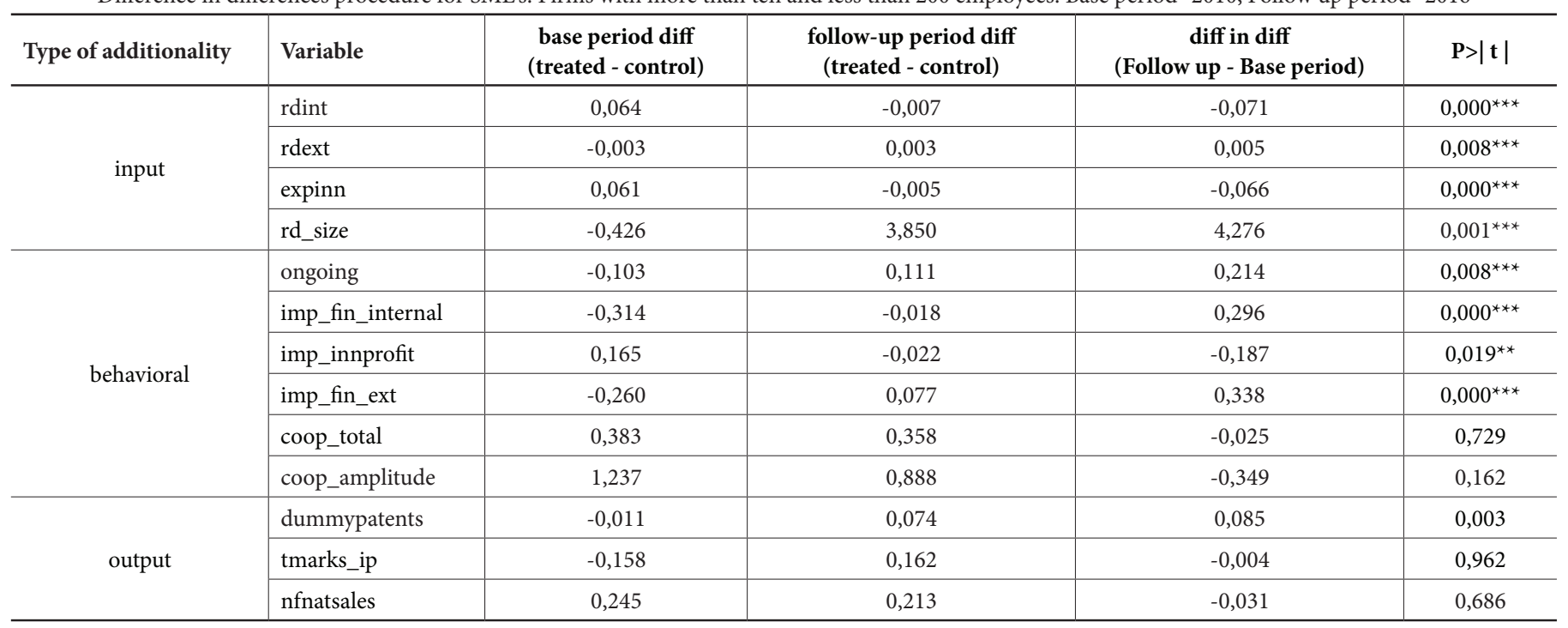

${ }^{* * *} \mathrm{p}<0.01 ;{ }^{* *} \mathrm{p}<0.05 ;{ }^{*} \mathrm{p}<0.1$

Number of observations in the base period 448 ( 8 treated, 440 controls); the number of observations in follow up period 254 (12 treated, 242 controls).

Source: Own calculations

ISSN: 0718-2724. (http://jotmi.org)

Journal of Technology Management \& Innovation ( ) Universidad Alberto Hurtado, Facultad de Economía y Negocios. 


\subsection{Results on big firms}

As can be seen in Table 5, big firms treated tend to have more R\&D internal expenditures than control firms do in the long term; therefore, we can say big firms in Colombia behave differently than SMEs, given that for the latter we found a crowding-out effect. At the same time, expenditures for acquiring external $\mathrm{R} \& \mathrm{D}$ tend to decrease in those types of firms. It seems that treated big firms tend to replace external by the internal generation of knowledge. At the same time, total expenditure seems to have no changes in the long term and in sum, it seems that the additionality of internal expenditure is controlled by the additionality of external expenditures on R\&D.
When we break down results of behavioral additionalities, it can be seen that treated firms having ongoing innovation projects seem to diminish against non-treated control firms; this could be interpreted as a counterintuitive result, but it is also possible that big firms tend to choose those projects in which they expect higher profits or those for which they have enough funding, diminishing ongoing projects in consequence. However, this result is to be researched in the future. By combining results of internal R\&D expenditure with those of the dummy of ongoing projects, we can expect that individual projects of big firms tend to be highly specialized and to have higher amounts of money.

Table 5. Average Treatment Effect on the Treated (ATET). Big firms.

\begin{tabular}{|c|c|c|c|c|c|}
\hline Type of additionality & Variable & $\begin{array}{l}\text { base period diff } \\
\text { (treated - control) }\end{array}$ & $\begin{array}{l}\text { follow-up period diff } \\
\text { (treated - control) }\end{array}$ & $\begin{array}{c}\text { diff in diff } \\
\text { (Follow up - Base period) }\end{array}$ & $\mathrm{P}>|\mathrm{t}|$ \\
\hline \multirow{4}{*}{ input } & rdint & $-0,148$ & 0,608 & 0,756 & $0,095^{*}$ \\
\hline & rdext & 0,701 & 0,005 & $-0,696$ & $0,000^{* * *}$ \\
\hline & expinn & 0,553 & 0,613 & 0,060 & 0,907 \\
\hline & rd_size & $-30,045$ & $-9,088$ & 20,957 & $0,005^{\star * *}$ \\
\hline \multirow{6}{*}{ behavioral } & ongoing & 0,032 & $-0,195$ & $-0,227$ & $0,018^{\star \star}$ \\
\hline & imp_fin_internal & 0,186 & 0,183 & $-0,003$ & 0,976 \\
\hline & imp_innprofit & $-0,165$ & $-0,285$ & $-0,120$ & 0,224 \\
\hline & imp_fin_ext & 0,463 & 0,294 & $-0,169$ & $0,075^{\star}$ \\
\hline & coop_total & 0,166 & 0,056 & $-0,11$ & 0,223 \\
\hline & coop_amplitude & 1,678 & 0,480 & $-1,198$ & $0,010^{* *}$ \\
\hline \multirow[t]{3}{*}{ output } & dummypatents & $-0,069$ & $-0,066$ & 0,003 & 0,924 \\
\hline & tmarks_ip & $-0,023$ & $-0,064$ & $-0,041$ & 0,664 \\
\hline & nfnatsales & 0,215 & 0,024 & $-0,191$ & $0,058^{*}$ \\
\hline
\end{tabular}

${ }^{* * *} \mathrm{p}<0.01 ;{ }^{* *} \mathrm{p}<0.05 ;{ }^{*} \mathrm{p}<0.1$

Number of observations in the base period 257 (13 treated, 244 controls); the number of observations in follow up period 177 ( 27 treated, 150 controls).

Source: Own calculations

Regarding external financial impediments, big firms tend to perceive fewer barriers after subsidy; this is contrary to what happens with SMEs. We believe big firms have already experienced innovation projects; therefore, those firms tend to decrease external financial impediments as a result of a positive innovation subsidy spillover. At the same time, cooperation amplitude is lower for big firms receiving subsidies; our interpretation of this result is that those firms tend to specialize their cooperation networks going from an atomized network to a specialized one.

Finally, results of output additionalities show us that big firms, just like SMEs do not have more patents or trademarks after subsidies, at the same time, and in the same direction of the results of the full sample, innovative revenues tend to decrease as firms receive more subsidies; we do not fully understand this results, but the same hypothesis posted for the full sample could apply in the case of big firms.

\section{Robustness check}

Lastly, as a robustness check, we perform several falsification tests for the period 2010. Let's remember that for our analysis, we use companies without subsidies in the period 2007-2008; therefore, we replicate our matching procedure for the 2008 survey and then, we test the impact of subsidies on several variables for the follow-up period of 2010. Given that in our sample, we have companies not receiving subsidies in the 2007-2008 period, firms should not display any effect linked to subsidies in the period 2010.

For our test we use variables like industrial secret (ind_sec, a dummy variable equal to one if the company protect its ideas with this type of protection and zero otherwise); non-disclosure agreements (non disa, a dummy variable equal to one if the company protect its ideas with this type of protection and zero otherwise); number of quality certifications obtained by the company in this period (cert_num); a 
variable taking into account if the company is using data from research centers or commerce chambers to generate innovation ideas (data_rcts; data_cc); and lastly, a dummy variable taking into account if the company perform innovation to improve quality of its goods and services (imp_gs). The selection of these variables lies in the fact that are measures that should not be affected by subsidies reception, and, as can be seen in appendix D., the checks confirm our inferences, the variables studied are not affected by subsidies in 2010 .

\section{Conclusions}

We developed a Conditional Difference in Difference methodology to determine the input, output, and behavioral additionality effects of subsidies to innovation for firms in Colombia, in the 2010-2016 period, using Colombia's innovation survey (EDIT). Our results reinforce the fact that innovation subsidies create positive additionalities on firms. Those additionalities can be seen in the long term, especially for input variables like internal $R \& D$ expenditures (rdint), total $R \& D$ expenditures (expinn), and the number of $\mathrm{R} \& \mathrm{D}$ employees ( $\mathrm{rd} \_$size).

On the other hand, we found that external expenditures on $R \& D$ (rdext) tend to be reduced after subsidies, and we believe this is an effect of internal knowledge generation against external acquisitions. This effect is visible especially, for big firms and the complete sample, and reinforces the fact that governments can reduce market imperfections using subsidies, given that most of the companies, tend to privilege the internal knowledge formation that generates internal spillover effects. For manager proposes, these results are essential. Also, companies without experience in the innovation field, can use government subsidies as a way to gain the initial needed capabilities in the process, even when this knowledge is obtained outside the company.

We found that behavioral additionalities are positive in the case of small and medium firms; these companies tend to increase the number of ongoing innovation projects showing that government subsidies induce companies to involve into innovation in the long-term. At the same time, we found out that the perception of internal and external financial impediments tend to increase after subsidies in SMEs. These results seem to be contra-intuitive, because one may think that firms should reduce their financial impediments perception once subsidies are granted; however, we hypothesize that most SMEs are not experienced in innovation; therefore, this is the result of a new vision of these firms about the innovation process. As is discussed in literature (Baldwin \& Lin, 2002; D’Este et al., 2012; Pellegrino \& Savona, 2017), we call this phenomena the experience effect; companies perceive impediments to innovation only after the involvement on innovation process, therefore, subsidies increase impediments perception given that before grants, SMEs are mostly not involved in innovation ventures. At the same time, another way to see this experience effect is that SMEs tend to perceive that innovation is more profitable once they receive subsidies. A company cannot say that innovation is good business without performing innovation projects, and only after the reception of subsidies, followed by involvement in innovation projects, companies perceive the benefits of the process.
On the other side, we find out that big firms, after subsidy grants, tend to diminish their perception of external financial barriers (imp_ fin_ext). In contrast to SMEs findings, it seems that big firms, that are experienced already, find relief in their financial impediments perception; This could be a proof for the experience effect generated in SMEs, given that is logic to think that big firms are already involved in innovation projects, and therefore, have lived in firsthand the effect of financial impediments, so subsidies, create the expected effect on big firms, diminishing obstacle's perception.

Output additionalities do not have positive results in our research. Patents and trademarks are not affected after subsidies; however, we found a negative impact on firm revenues only for big firms. Although we do not fully understand this phenomenon, we believe this could be caused by the way we measure revenues (new to the firm), and possibly, is non-observed additionality on new to the market revenues, that is, the weighted complement of our measure. The fact that we cannot find any output additionalities lead us to look for other ways to measure these type of impacts, and the CDM model (Crepon, Duguet, \& Mairessec, 1998), could be a right approach in the case of productivity increase related to subsidies, even when recent literature point out to a negative result in this field (Czarnitzki \& Delanote, 2017).

Our results have important messages for policymakers. For one side, in contrast to big firms, SMEs in Colombia seem to have stable additionalities produced by subsidies. Therefore, policies to innovation should privilege the selection of SMEs that most of the time are not involved in innovation, given that subsidies introduce an experience effect, making companies get involved in innovation ventures. However, must of the time, innovation policies are directed to big firms given the logic of "picking the winner" used by governments around the world. Our results point out that this type of policy should produce minor effects on market spillovers.

Second, dividing our sample, we found out that big firms and SMEs tend to behave differently after subsidies; therefore, policymakers should avoid programs in which all companies are considered under the same umbrella. If behavior after subsidy is dissimilar, program characteristics should be also different in order to increase the likelihood of obtaining innovation spillover in each type of company, in this case, SMEs and big firms.

\section{References}

Aboal, D., \& Garda, P. (2015). Does public financial support stimulate innovation and productivity? An impact evaluation. Recuperado de http://repositorio.cepal.org/handle/11362/38832

Aerts, K., \& Czarnitzki, D. (2004). Using Innovation Survey Data to Evaluate R\&D Policy: The Case of Belgium. SSRN Electronic Journal, (04), 1-25. https://doi.org/10.2139/ssrn.572086

Aerts, K., \& Schmidt, T. (2008). Two for the price of one?: Additionality effects of R\&D subsidies: A comparison between Flanders and Germany. Research Policy, 37(5), 806-822. https://doi.org/10.1016/J. RESPOL.2008.01.011 
Almus, M., \& Czarnitzki, D. (2003). The Effects of Public R\&D Subsidies on Firms' Innovation Activities. Journal of Business \& Economic Statistics, 21(2), 226-236. https://doi.org/10.1198/073500103288618918

Arrow, K. J. (1972). Economic Welfare and the Allocation of Resources for Invention. En Readings in Industrial Economics (pp. 219-236). https://doi.org/10.1007/978-1-349-15486-9_13

Autio, E., Kanninen, S., \& Gustafsson, R. (2008). First- and secondorder additionality and learning outcomes in collaborative $R \& D$ programs. Research Policy, 37(1), 59-76. https://doi.org/10.1016/j. respol.2007.07.012

Baldwin, J., \& Lin, Z. (2002). Impediments to advanced technology adoption for Canadian manufacturers. En Research Policy (Vol. 31). Recuperado de www.statcan.ca.

Barrios, F., Forero, C., \& Perry, G. (2018). Public financial support and innovation in Colombian manufacturing firms. Working papers, 7, 1-35. Recuperado de http://www.scioteca.caf.com/handle/123456789/1159

Bodas-Freitas, I., Castellacci, F., Fontana, R., Malerba, F., \& Vezzulli, A. (2017). Sectors and the additionality effects of R\&D tax credits: A cross-country microeconometric analysis. Research Policy, 46(1), 57-72. https://doi.org/10.1016/j.respol.2016.10.002

Busom, I. (2000). An Empirical Evaluation of The Effects of R\&D Subsidies. Economics of Innovation and New Technology, 9(2), 111148. https://doi.org/10.1080/10438590000000006

Busom, I., \& Vélez-Ospina, J. A. (2017). Innovation, Public Support, and Productivity in Colombia. A Cross-industry Comparison. World Development, 99, 75-94. https://doi.org/10.1016/J. WORLDDEV.2017.07.005

Catozzella, A., \& Vivarelli, M. (2011). Beyond Additionality: Are Innovation Subsidies Counterproductive? IZA working paper, (5746). Recuperado de https://papers.ssrn.com/sol3/papers.cfm?abstract_ $\mathrm{id}=1863068$

Cerulli, G. (2010, septiembre 1). Modelling and Measuring the Effect of Public Subsidies on Business R\&D: A Critical Review of the Econometric Literature. Economic Record, Vol. 86, pp. 421-449. https://doi. org/10.1111/j.1475-4932.2009.00615.x

Cerulli, G., \& Potì, B. (2008). Evaluating the Effect of Public Subsidies on firm R\&D activity: an Application to Italy Using the Community Innovation Survey. 9. Recuperado de http://www.ceris.cnr.it/ceris/ workingpaper/2008/WP_9_08_CERULLI_POTI.pdf

Cerulli, G., \& Potì, B. (2016). Explaining firm sensitivity to R\&D subsidies within a dose-response model: The role of financial constraints, real cost of investment, and strategic value of R\&D. En DEM Working Papers. Recuperado de Department of Economics and Management website: https://ideas.repec.org/p/trn/utwprg/2016-09.html
Choi, J., \& Lee, J. (2017). Repairing the R\&D market failure: Public $\mathrm{R} \& \mathrm{D}$ subsidy and the composition of private R\&D. Research Policy, 46(8), 1465-1478. https://doi.org/10.1016/j.respol.2017.06.009

Chudnovsky, D., Lopez, A., Rossi, M., \& Ubfal, D. (2006). Evaluating a program of public funding of private innovation activities . An econometric study of FONTAR in Argentina. 1-42. Recuperado de https:// publications.iadb.org/handle/11319/2829

Cin, B. C., Kim, Y. J., \& Vonortas, N. S. (2017). The impact of public R\&D subsidy on small firm productivity: evidence from Korean SMEs. Small Business Economics, 48(2), 345-360. https://doi. org/10.1007/s11187-016-9786-x

Clarysse, B., Wright, M., \& Mustar, P. (2009). Behavioural additionality of R\&D subsidies: A learning perspective. Research Policy, 38(10), 1517-1533. https://doi.org/10.1016/j.respol.2009.09.003

Crepon, B., Duguet, E., \& Mairessec, J. (1998). Research, Innovation And Productivity: An Econometric Analysis At The Firm Level. Economics of Innovation and New Technology, 7(2), 115-158. https://doi. org/10.1080/10438599800000031

Crespi, G. A., \& Maffioli, A. (2014). Design and evaluation of fiscal incentives for business innovation in Latin America: Lessons learned after 20 years of experimentation. En Science, Technology and Innovation Policies for Development: The Latin American Experience (pp. 225-253). https://doi.org/10.1007/978-3-319-04108-7_10

Crespi, G., Garone, L. F., Maffioli, A., \& Melendez, M. (2015). Longterm productivity effects of public support to innovation in Colombia. Emerging Markets Finance and Trade, 51(1), 48-64. https://doi.or g/10.1080/1540496X.2015.998080

Crespi, G., Giuliodori, D., Giuliodori, R., \& Rodriguez, A. (2016). The effectiveness of tax incentives for R\&amp;D+i in developing countries: The case of Argentina. Research Policy, 45(10), 2023-2035. https://doi.org/10.1016/J.RESPOL.2016.07.006

Czarnitzki, D., \& Delanote, J. (2015). R\&D policies for young SMEs: input and output effects. Small Business Economics, 45(3), 465-485. https://doi.org/10.1007/s11187-015-9661-1

Czarnitzki, D., \& Delanote, J. (2017). Incorporating innovation subsidies in the CDM framework: empirical evidence from Belgium. Economics of Innovation and New Technology, 26(1-2), 78-92. https:// doi.org/10.1080/10438599.2016.1202514

Czarnitzki, D., Ebersberger, B., \& Fier, A. (2007). The relationship between R\&D collaboration, subsidies and R\&D performance: Empirical evidence from Finland and Germany. Journal of Applied Econometrics, 22(7), 1347-1366. https://doi.org/10.1002/jae.992

Czarnitzki, D., \& Hussinger, K. (2018). Input and output additionality of R\&D subsidies. Applied Economics, 1-18. https://doi.org/10.1080/ 00036846.2017 .1361010 
Czarnitzki, D., \& Lopes-Bento, C. (2012). Evaluation of public R\&D policies: a cross-country comparison. World Review of Science, Technology and Sustainable Development, 9(2), 254-282. https://doi. org/10.1504/wrstsd.2012.047690

Czarnitzki, D., \& Lopes-Bento, C. (2013, febrero 1). Value for money? New microeconometric evidence on public R\&D grants in Flanders. Research Policy, Vol. 42, pp. 76-89. https://doi.org/10.1016/j.respol.2012.04.008

Czarnitzki, D., \& Lopes-Bento, C. (2014). Innovation Subsidies: Does the Funding Source Matter for Innovation Intensity and Performance? Empirical Evidence from Germany. Industry and Innovation, 21(5), 380-409. https://doi.org/10.1080/13662716.2014.973246

D'Este, P., Iammarino, S., Savona, M., \& von Tunzelmann, N. (2012). What hampers innovation? Revealed barriers versus deterring barriers. Research Policy, 41(2), 482-488. https://doi.org/10.1016/J.RESPOL.2011.09.008

David, P. A., Hall, B. H., \& Toole, A. A. (2000). Is public R\&D a complement or substitute for private $\mathrm{R} \& \mathrm{D}$ ? A review of the econometric evidence. Research Policy, 29(4-5), 497-529. https://doi.org/10.1016/ S0048-7333(99)00087-6

Dimos, C., \& Pugh, G. (2016). The effectiveness of R\&D subsidies: A meta-regression analysis of the evaluation literature. Research Policy, 45(4), 797-815. https://doi.org/10.1016/J.RESPOL.2016.01.002

Engel, D., Rothgang, M., \& Eckl, V. (2016). Systemic aspects of R\&D policy subsidies for R\&D collaborations and their effects on private R\&D. Industry and Innovation, 23(2), 206-222. https://doi.org/10.108 0/13662716.2016.1146127

Färe, R., Grosskopf, S., Fukuyama, H., \& Margaritis, D. (2011). DEA and endogenous technological change. European Journal of Operational Research, 210(2), 457-458. https://doi.org/10.1016/j. ejor.2010.09.033

Fernández-Sastre, J., \& Martín-Mayoral, F. (2015). The effects of developing-countries' innovation support programs: evidence from Ecuador. Innovation, 17(4), 466-484. https://doi.org/10.1080/144793 38.2016.1157447

Garcia, A., \& Mohnen, P. (2010). Impact of government support on R\&D and innovation. Unu-Merit, (31), 26. https://doi.org/10.1111/ j.1467-629X.1980.tb00220.x

González, X., \& Pazó, C. (2008). Do public subsidies stimulate private R\&D spending? Research Policy, 37(3), 371-389. https://doi. org/10.1016/j.respol.2007.10.009

Görg, H., \& Strobl, E. (2007). The effect of R\&D subsidies on private R\&D. Economica, 74(294), 215-234. https://doi.org/10.1111/j.14680335.2006.00547.x
Guo, D., Guo, Y., \& Jiang, K. (2016). Government-subsidized R\&D and firm innovation: Evidence from China. Research Policy, 45(6), 1129-1144. https://doi.org/10.1016/j.respol.2016.03.002

Hall, B. H., \& Lerner, J. (2009). The financing of R\&D and innovation. Handbook of the Economics of Innovation, 1(1 C), 609-639. https:// doi.org/10.1016/S0169-7218(10)01014-2

Heshmati, A., \& Lööf, H. (2005). Sources of Finance, R\&D Investment and Productivity: 1(11), 1-26. Recuperado de http://www.infra.kth. se/cesis/research/workpap.htm

Howell, A. (2017). Picking 'winners' in China: Do subsidies matter for indigenous innovation and firm productivity?' China Economic Review, 44, 154-165. https://doi.org/10.1016/j.chieco.2017.04.005

Jaffe, A. B., Trajtenberg, M., \& Henderson, R. (1993). Geographic Localization of Knowledge Spillovers as Evidenced by Patent Citations. The Quarterly Journal of Economics, 108(3), 577-598. https://doi. org/10.2307/2118401

Jaramillo, H., Lugones, F., \& Salazar, M. (2000). Normalización de indicadores de innovación tecnológica en América Latina y el Caribe :manual de Bogotá. Recuperado de http://www.sidalc.net/cgi-bin/ wxis.exe/?IsisScript=BAC.xis\&method=post $\&$ formato $=2 \&$ cantidad $=$ 1 \&expresion $=\mathrm{mfn}=044526$

Jiang, C., Zhang, Y., Bu, M., Liu, W., Jiang, C., Zhang, Y., ... Liu, W. (2018). The Effectiveness of Government Subsidies on Manufacturing Innovation: Evidence from the New Energy Vehicle Industry in China. Sustainability, 10(6), 1692. https://doi.org/10.3390/su10061692

Karhunen, H., \& Huovari, J. (2015). R\&D subsidies and productivity in SMEs. Small Business Economics, 45(4), 805-823. https://doi. org/10.1007/s11187-015-9658-9

Lach, S. (2002). Do R\&D Subsidies Stimulate or Displace Private $\mathrm{R} \& \mathrm{D}$ ? Evidence from Israel. Journal of Industrial Economics, 50(4), 369-390. https://doi.org/10.1111/1467-6451.00182

Nelson, R. R. (1959). The Simple Economics of Basic Scientific Research. Journal of Political Economy, 67(3), 297-306. https:/doi. org/10.1086/258177

OCyT. (2017). Informe Anual de Indicadores de Ciencia y Tecnología 2016. Recuperado de http://ocyt.org.co/proyectos-y-productos/ informe-anual-de-indicadores-de-ciencia-y-tecnologia-2016/

OECD. (2005). Oslo Manual: Guidelines for Collecting and Interpreting Innovation Data. En Communities. https://oi. org/10.1787/9789264013100-en

OECD, \& Eurostat. (1997). Proposed Guidelines for Collecting and Interpreting Technological Innovation Data. https://doi. org/10.1787/9789264192263-en 
Pellegrino, G., \& Savona, M. (2017). No money, no honey? Financial versus knowledge and demand constraints on innovation. Research Policy, 46(2), 510-521.https://doi.org/10.1016/J.RESPOL.2017.01.001

Rosenbaum, P. R., \& Rubin, D. B. (1983). The central role of the propensity score in observational studies for causal effects. Biometrika, 70(1), 41-55. https://doi.org/10.1093/biomet/70.1.41

Sanguinetti, P. (2005). Innovation and R\&D expenditures in Argentina: evidence from a firm level survey. Universidad Torcuato Di Tella, Department of ..., 1-46. Recuperado de http://www.crei.cat/conferences/RandD_and_Innovation_in_the_Development_Process/activities/sc_conferences/23/papers/sanguinetti.pdf

Tello, M. D. (2015). Firms' innovation, public financial support, and total factor productivity: The case of manufactures in Peru. Review of Development Economics, 19(2), 358-374. https://doi.org/10.1111/ rode. 12147
Villa, J. M. (2016). diff: Simplifying the estimation of difference-indifferences treatment effects. Stata Journal, 16(1), 52-71. Recuperado de https://ideas.repec.org/a/tsj/stataj/v16y2016i1p52-71.html

Wanzenböck, I., Scherngell, T., \& Fischer, M. M. (2013). How do firm characteristics affect behavioural additionalities of public R\&D subsidies? Evidence for the Austrian transport sector. Technovation, 33(23), 66-77. https://doi.org/10.1016/J.TECHNOVATION.2012.11.006

Widmann, R. (2016). The Effect of Government Research Grants on Firm Innovation: Theory and Evidence from Austria* (December). Recuperado de http://www.kellogg.northwestern.edu/faculty/widmann/Papers/Government Research Grants/Widmann_Government_Research_Grants.pdf

Zúñiga-Vicente, J. Á., Alonso-Borrego, C., Forcadell, F. J., \& Galán, J. I. (2014). ASSESSING THE EFFECT OF PUBLIC SUBSIDIES ON FIRM R\&D INVESTMENT: A SURVEY. Journal of Economic Surveys, 28(1), 36-67. https://doi.org/10.1111/j.1467-6419.2012.00738.x 


\section{Appendix A. Summary of used variables}

\begin{tabular}{|c|c|c|c|}
\hline & Variable & Description & Measurement \\
\hline \multirow{5}{*}{ Probit } & treated & The firm receives subsidies in that particular year. & Dummy $1=y e s ; 0=$ no \\
\hline & medium_tech & Belonging to a medium technology sector & Dummy $1=y e s ; 0=$ no \\
\hline & medhigh_tech & Belonging to a medium high technology sector & Dummy $1=$ yes; $0=$ no \\
\hline & and_reg & Firm located in Andean Region & Dummy $1=$ yes; $0=$ no \\
\hline & bog_reg & Firm located on Bogotá & Dummy $1=$ yes; $0=$ no \\
\hline Input & rdint & Mean of internal expenditure on $R \& D$ in $t$ and $t-1$ & Millions of COP\$ \\
\hline \multirow{6}{*}{ Behavioral } & ongoing & Does the firm have ongoing $\mathrm{R} \& \mathrm{D}$ projects? & Dummy $1=y e s ; 0=$ no \\
\hline & imp_fin_intl & Does the firm perceive a lack of internal financial founds? & Dummy $1=$ yes; $0=$ no \\
\hline & imp_innprofit & Does the firm perceive that innovation is not profitable? & Dummy $1=y e s ; 0=$ no \\
\hline & imp_fin_ext & Does the firm perceive a lack of external financial founds? & Dummy $1=$ yes; $0=$ no \\
\hline & coop_total & Does the firm cooperate for $\mathrm{R} \& \mathrm{D}$ in the last two years? & Dummy $1=y e s ; 0=$ no \\
\hline & coop_amplitude & Types of institutions in which cooperation is carried out & Number of typologies, $\max =11$ \\
\hline
\end{tabular}




\section{Appendix B. Descriptive statistics}

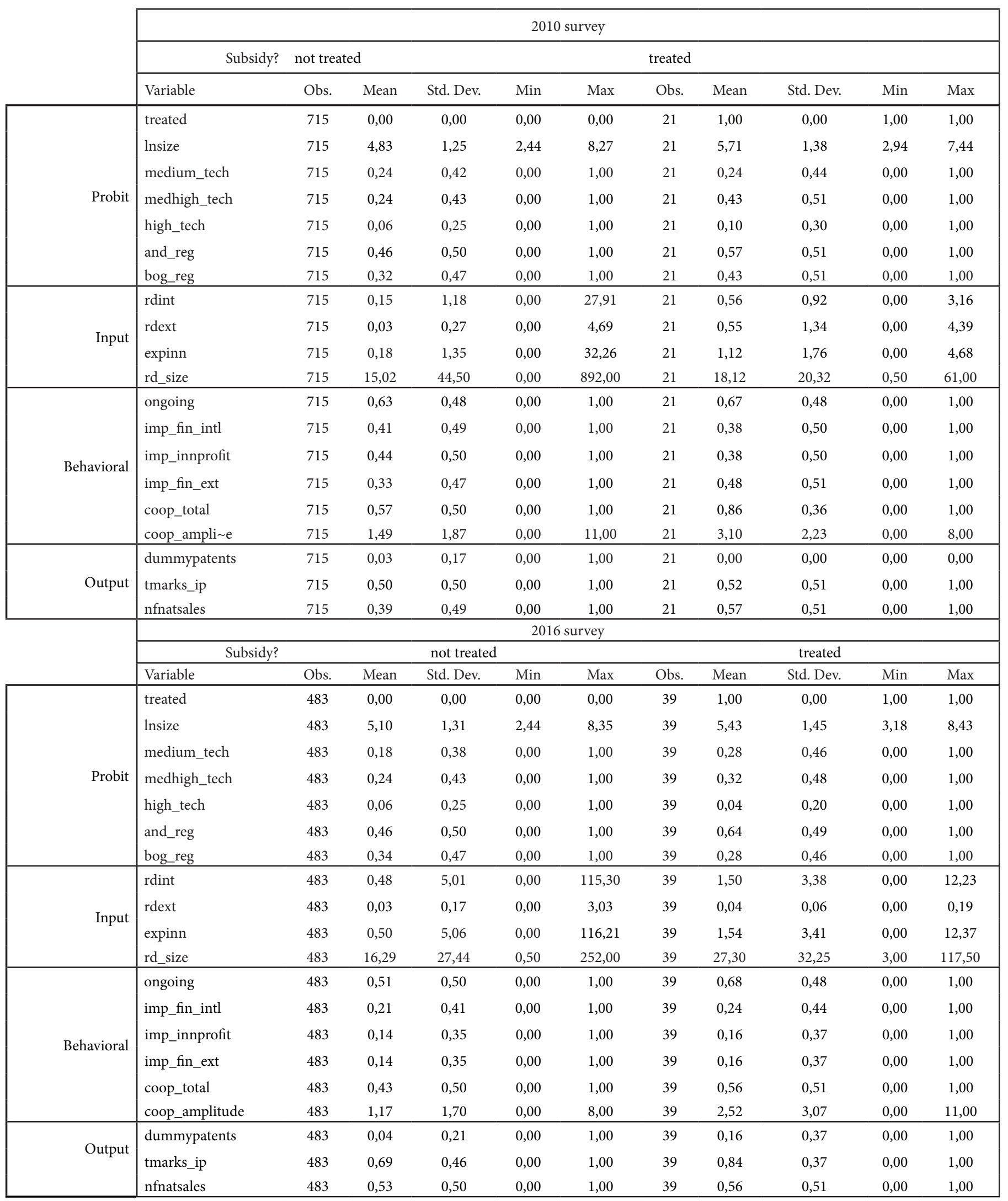




\section{Appendix C. Common support analysis}

\begin{tabular}{|c|c|c|c|c|c|c|c|c|c|c|c|c|c|}
\hline & Variable & C & $\mathrm{T}$ & $\mathrm{C}$ & $\mathrm{T}$ & C & $\mathbf{T}$ & $\mathrm{C}$ & $\mathrm{T}$ & C & $T$ & C & $\mathbf{T}$ \\
\hline Block 2 & $\begin{array}{l}\text { obs } \\
\text { mean } \\
\text { diff } \\
\text { p value }\end{array}$ & $\begin{array}{c}20 \\
6,45\end{array}$ & $\begin{array}{c}1 \\
7,43\end{array}$ & $\begin{array}{c}20 \\
0,05\end{array}$ & $\begin{array}{c}1 \\
1,00\end{array}$ & $\begin{array}{c}20 \\
0,85\end{array}$ & $\begin{array}{c}1 \\
0,00\end{array}$ & $\begin{array}{c}20 \\
0,00\end{array}$ & $\begin{array}{c}1 \\
0,00\end{array}$ & $\begin{array}{c}20 \\
0,60\end{array}$ & $\begin{array}{c}1 \\
1,00 \\
\end{array}$ & $\begin{array}{c}20 \\
0,40\end{array}$ & $\begin{array}{c}1 \\
0,00\end{array}$ \\
\hline Block 3 & $\begin{array}{l}\text { obs } \\
\text { mean } \\
\text { diff } \\
\text { p value }\end{array}$ & $\begin{array}{c}7 \\
6,84 \\
\end{array}$ & $\begin{array}{c}3 \\
7,19\end{array}$ & $\begin{array}{c}7 \\
0,14\end{array}$ & $\begin{array}{c}3 \\
0,33\end{array}$ & $\begin{array}{c}7 \\
0,57\end{array}$ & $\begin{array}{c}3 \\
0,66\end{array}$ & $\begin{array}{c}7 \\
0,29\end{array}$ & $\begin{array}{c}3 \\
0,00\end{array}$ & $\begin{array}{c}7 \\
0,57\end{array}$ & $\begin{array}{c}3 \\
0,00\end{array}$ & $\begin{array}{c}7 \\
0,43\end{array}$ & $\begin{array}{c}3 \\
1,00 \\
7\end{array}$ \\
\hline Block 4 & $\begin{array}{l}\text { obs } \\
\text { mean } \\
\text { diff } \\
\text { p value }\end{array}$ & $\begin{array}{c}1 \\
7,72\end{array}$ & $\begin{array}{c}3 \\
7,39\end{array}$ & $\begin{array}{c}1 \\
0,00\end{array}$ & $\begin{array}{c}3 \\
0,00\end{array}$ & $\begin{array}{l}1 \\
1\end{array}$ & $\begin{array}{c}3 \\
1,00\end{array}$ & $\begin{array}{c}1 \\
0,00\end{array}$ & $\begin{array}{c}3 \\
0,00\end{array}$ & $\begin{array}{c}1 \\
1,00\end{array}$ & $\begin{array}{c}3 \\
1,00\end{array}$ & $\begin{array}{c}1 \\
0,00\end{array}$ & $\begin{array}{c}3 \\
0,00\end{array}$ \\
\hline
\end{tabular}

${ }^{* * *} \mathrm{p}<0.01 ;{ }^{* *} \mathrm{p}<0.05 ;{ }^{*} \mathrm{p}<0.1$

$\mathrm{T}=$ Treated; $\mathrm{C}=$ Control. $\mathrm{N}=736$ firms

After block 4, there are no controls. For single observations, there are no Standard Deviations; therefore, we cannot calculate

P.Values for blocks 2 and 4 .

\section{Appendix D. Falsification tests}

Falsification test.

Difference in differences procedure for firms with more than ten employees and receiving subsidy in 2010. Base period=2008; Follow up period $=2010$

\begin{tabular}{cccccc}
\hline Type of additionality & Variable & $\begin{array}{c}\text { base period diff } \\
\text { (treated } \text { - control) }\end{array}$ & $\begin{array}{c}\text { follow-up period diff } \\
\text { (treated } \text { - control) }\end{array}$ & $\begin{array}{c}\text { diff in diff (Follow up - } \\
\text { Base period) }\end{array}$ \\
\hline \multirow{2}{*}{ Not related with subsidies } & ind_sec & $-0,078$ & $-0,122$ & $-0,044$ \\
& non_da & $-0,111$ & $-0,097$ & 0,014 \\
& cert_num & $-3,334$ & $-1,482$ & 1,852 & 0,309 \\
& data_rcts & $-0,097$ & $-0,094$ & 0,003 & 0,804 \\
& data_cc & $-0,007$ & $-0,003$ & 0,004 & 0,936 \\
\hline
\end{tabular}

${ }^{* * *} \mathrm{p}<0.01 ;{ }^{* *} \mathrm{p}<0.05 ;{ }^{*} \mathrm{p}<0.1$

Number of observations in the base period 454 (12 treated, 442 controls); the number of observations in follow up period 259 (14 treated, 245 controls). 
